PRINT ISSN 1119-8362

Electronic ISSN 1119-8362
Full-text Available Online at

https://www.ajol.info/index.php/jasem

http://ww.bioline.org.br/ja
J. Appl. Sci. Environ. Manage.

Vol. 25 (8) 1505-1512 August 2021

\title{
Assessment of the Physicochemical Parameters of Bodo Creek, Rivers State, Nigeria: A Pre-spill, Post-spill and Post-clean-up Review
}

\author{
${ }^{* 1}$ NKEEH, DK; ${ }^{2} \mathrm{HART}$, AI; ${ }^{3} \mathrm{ERONDU}, \mathrm{ES} ;{ }^{3} \mathrm{ZABBEY}, \mathrm{N}$ \\ ${ }^{* 1}$ Department of Environmental Technology and Management, World Bank Africa Centre of Excellence, Centre for Oilfield Chemicals \\ Research, University of Port Harcourt, Choba, P.M.B.5323, Rivers State, Nigeria. \\ ${ }^{2}$ Department of Animal and Environmental Biology, Faculty of Science, University of Port Harcourt, Choba, P.M.B.5323, Rivers State, \\ Nigeria. \\ ${ }^{3}$ Department of Fisheries, Faculty of Agriculture, University of Port Harcourt, Choba, P.M.B.5323, Rivers State, Nigeria. \\ *Corresponding Author Email: kootedumbari@gmail.com
}

\begin{abstract}
Water bodies are a source of ecosystem services such as water supply, production, recreation, and aesthetics. In 2008, two major oil spills took place in Bodo creek. A major challenge with the assessment and monitoring of an environment is the lack of baseline data. However, Bodo Creek has been studied extensively. This paper, therefore, reviews pre-spill, post-spill, and post-clean-up studies on physicochemical parameters in Bodo Creek. This paper revealed that the difference in the levels of the physicochemical parameters including $\mathrm{pH}$, salinity, dissolved oxygen (DO), biochemical oxygen demand (BOD), and temperature in Bodo Creek, before and after the oil spill was not statistically significant $(\mathrm{P}>0.05)$; other physicochemical parameters examined in this paper are alkalinity, total hardness, chemical oxygen demand (COD) and total dissolved solids (TDS). This paper also revealed that $\mathrm{pH}$ and temperature were higher in the post-cleanup study, while DO and conductivity were higher in the pre-cleanup study. BOD was significantly higher in the post-spill study than the pre-spill study, indicating a high level of pollution as a result of the oil spill. This review also shows that there are higher $\mathrm{pH}$ and temperature levels in post-clean-up studies than the pre-cleanup studies. Preclean-up DO and conductivity were higher than the levels in the post-clean-up study.
\end{abstract}

\section{DOI:https://dx.doi.org/10.4314/jasem.v25i8.34}

Copyright: Copyright $(\odot 2021$ Nkeeh et al. This is an open access article distributed under the Creative Commons Attribution License (CCL), which permits unrestricted use, distribution, and reproduction in any medium, provided the original work is properly cited.

Dates: Received: 10 May 2021; Revised: 28 June 2021; Accepted: 01 July 2021

Keywords: Water quality, pre-spill, post-spill, Bodo Creek, and Physico-chemical

Water is a basic life-supporting system for the survival, growth, and reproduction of aquatic organisms. Water also serves as a means by which fishing boats or fishing trawls are moved from one point to the other, for small-scale fish farmers and industrial fishers respectively. According to Awah (2008), water is a basic component of the changing aquatic life-supporting system for the dissolution or suspension of organic and inorganic substances and supports the existence of an interactional relationship between wide varieties of organisms. According to a study by Onwugbuta-Enyi et al. (2008), water bodies are a source of ecosystem services, for example, water supply, production, recreation, and aesthetics; the availability of water inadequate quality and quantity contributes to health maintenance,human activities deteriorate surface water. Zabbey and Arimoro (2017) identified hydrology, Physico-chemical parameters, and biological communities as the three basic components of water quality studies. According to their report, sediment and interstitial water environmental quality are linked mutually to the changing conditions of the overlying water column, due to bottom-up and top-down fluxes between the ecological parameters of the two components, depending on the surrounding ambient conditions. According to Onwugbuta-Enyi et al. (2008), Physicochemical and biological factors determine the quality of any given water body, as there is an interactional relationship between these factors and with an intrinsic parameter of each variable to highly determine the water quality characteristics. Water quality affects the composition of species, distribution, and assemblages of plankton, benthos, and fish. Water body pollution in the developing countries has reached an alarming state, Nigeria inclusive. There are several works of literature for Physico-chemical parameters of surface water in Nigeria (Vincent et al., 2020). According to Vincent-Akpu and Nwachukwu (2016), water bodies have been exposed to different forms of degradation as a result of pollution coming from domestic waste, industrial activities; runoffs from agriculture and transportation activities. They further stressed that recently, transportation activities have been associated with increasing levels of environmental impact.Their study also revealed that using waterways for inland navigation may be a source of threat to aquatic organisms and can have significant 
impacts on the water bodies. The impact includes the change in hydrological conditions; water quality deterioration and as a source of pollutant emission. They also reported that there is an increase in the demand for water transport; resulting in chemical substances (especially oil) spills from ships, the release of nutrient overload, and invasion by species representing an important aspect of water quality. Some of the wastes from water transportation are sewage, gray and bilge water, gas emissions, solid and hazardous waste, with metals, mineral oil and lubricants, and organic substances as main constituents.

Bodo is a coastal community located in Gokana Local Government Area, Ogoni in Rivers State, Niger Delta, Nigeria. Other Local Government Areas that make up Ogoni are Khana, Tai, and Eleme. Politically, Bodo community is in the southeast Senatorial District of Rivers State. Bodo is a rural community occupying (latitude $48366^{\prime} \mathrm{N}$, longitude $7821^{\prime} \mathrm{E}$ ) in the upper reaches of the Andoni-Bonny estuarine ecosystem. Mangrove swamps, some island forests, and brackish water creeks occupy over $65 \%$ of the community. This is generally called Bodo Creek. Every day, the creeks in Bodo are exposed and submerged due to the influence of the low and high tide, respectively. The community is divided into 35 villages under the leadership of a monarch king and his council of chiefs (Onwugbuta-Enyi et al., 2008).

Crude Oil Exploration and Exploitation, Oil Spill and Its Effects on Water Quality:For over 5 decades, the exploration and exploitation of crude oil have been the major contributor to the economy of Nigeria. There is a significant oil reserve and natural gas, estimated at 37.4 billion barrels (OPEC, 2017) and 192 trillion standard cubic feet, respectively, in the Niger Delta region, which produces the oil. Crude oil in marketable quantity was first discovered in Oloibiri, Bayelsa State, Nigeria in the year 1956 (NDDC, 2001; Okonta, 2008). Twenty years later (1958), crude oil was discovered in second commercial quantity at the oil field in Bomu, Ogoni, Rivers State. The later discovery of oil made a significant contribution to the first export of oil from Nigeria to other countries. This was later expanded to fifty-seven oil wells, having five flow stations in Ogoni. There is a flow station called Bodo West field located in Bodo Creek mangrove mainland, Ogoni (UNEP, 2011; Linden and Palsson, 2013; Zabbey and Uyi, 2014). In 2008, two major oil spills occurred in Bodo Creek (Nkeeh et al., 2021). Although two major oil spills resulted from the activity of oil multinationals in Bodo Creek in 2008, oil spill from artisanal refining of crude oil is also a major challenge impacting negatively on Bodo Creek.
According to a study by Sibe et al. (2019), artisanal refining is used to describe the illegitimate distillation of crude oil in locally constructed stills. This activity has greatly heightened the level of environmental pollution and degradation as a result of oil exploration and exploitation. The study further stated that artisanal refinery is usually cited on the coastline of creeks, lakes, seas, e.t.c., thus destroying the biodiversity and leading to ecological imbalance. Also, in Bodo West, in Bonny LGA, an increase in artisanal refining between 2007 and 2011 has been accompanied by 10 percent of healthy mangrove cover, or $307,381 \mathrm{~m}^{2}$.According to Sibe et al. (2019), crude oil is released into the sea, creeks, during bunkering, transportation of the crude to site, and during the refining process. Bunkered oil is transported by canoe which mostly has leakages that allow for seepages into the river. Their study, however, reported that the main source of hydrocarbon contamination from artisanal refining is accidental disposal of crude oil, refined fractions, and indiscriminate storage of the heavy and bottom fractions of the petroleum refining process. Heavier fractions such as bitumen and lubricating oil cannot be processed by the refinery facilities. Therefore, they are usually stored or disposed of in pits around the refining sites. According to Attah (2012), the process is highly inefficient that most likely as much as 80 percent of the bottom fractions of the crude oil cannot be refined and are therefore discharged indiscriminately into the environment; which are eventually washed into the sea, river or lake when the tide is high and are deposited at the foreshore and seabed (Sibe et al., 2019). The Niger Delta over the years has experienced several oil spill incidents. According to Dan-Kalio and Braide (2002), there could be disastrous consequences following oil pollution and Nigeria has experienced some disasters from oil blowouts in addition to oil pollution from other sources. This includes blowouts and pipeline leakages from the Shell-Bp Bomu 11 in 1970, the Safran (now Elf) Obagi 21 blowout of 1972, the Texaco blowout of 1980, and the AgipOyakama pipeline leakage of 1980, have all led to disastrous impacts on land, freshwater swamps, and the marine environment. Globally, there have been recorded incidents of major oil spills. This ranges from the World's largest known oil spill known as the Persian Gulf War Oil Spill in 1991, to BP's Deepwater Horizon oil spill in 2010. Other major oil spills include; the Ixtoc 1 Oil Spill (1979), the Atlantic Empress Oil Spill (1979) and the Mingbulak (or Fergana Valley) Oil Spill (1992), the Kolva River Spill (1994), the Incidents at the Nowruz Oil Field, the Castillo de Bellver Oil Spill (1983) and the Amoco Cadiz Oil Spill (1978) (EBI, 2021). Oil spills have a potential negative impact on the stability of freshwater 
and marine ecosystems, having been reported to impact negatively on near-shore biodiversity (Smeltz et al. 2017) and functioning (Kotta et al. 2007; Venosa and Zhu 2005). In the Niger Delta region of Nigeria, reputed as the Nation's oil and gas region, there is the frequent occurrence of oil spills and the impacts persist as a result of the poor management regimes for clean-up and remediation (UNEP 2011; Sam et al. 2017a). Studies have shown that contamination resulting from oil spill incidents have the potential to alter the hydrology, disrupt plant-water relation, reduce the exchange of oxygen, lead to growth inhibition and reduction in fish production, and interfere with the ecological food chain and web (Ko and Day 2004; Nwipie et al., 2019).

Global Overview of Physicochemical Parameters of Water: In a study on the evaluation of Physicochemical parameters of Manchar Lake water, Pakistan, and their comparison with other global published values by Arain et al. (2008), they concluded that the water samples of the study area are polluted; they attributed this to wastewater coming from agricultural land as well as domestic wastes of Urban areas. The correlation study on Physicochemical parameters and quality assessment of Kosi River Water, Uttarakhand, India, revealed that all the measured physico-chemistry of the study area are within the WHO maximum permissible limit. The only exemptions were turbidity and BOD (Bhandari and Nayal, 2008). According to Simpi et al. (2011), in the analysis of water quality using Physico-chemical parameters of Hosahali Tank in Shimoga District, Karnataka, India, stated that all measured Physicochemical parameters were within the permissible limits. Gereyohannes et al. (2015) in the investigation of Physico-chemical parameters and its pollution implications of Ella River, Mekelle, Tigray, Ethiopia reported that throughout the river, there was pollution generally. Their study further stated that the pollution poses a danger to aquatic lives, the river as well as those who use it for domestic applications and other activities. According to Mezegbe et al. (2015) in the assessment of physico-chemical parameters of TsaedaAgam River in Mekelle City, Tigray, Ethiopia stated that most of the Physico-chemical parameters exceeded the WHO permissible limit for drinking water. The study however noted that the water can be used for irrigation because most of the parameters are within the FAO permissible limit. Adeyemo et al. (2008) evaluated the seasonal changes in Physicochemical parameters and nutrient load of river sediments in Ibadan City, Nigeria. They reported that the Physico-chemical quality of water in the study area was deteriorating at an alarming rate. Edori et al. (2020) evaluated the variation of some Physico- chemical parameters in surface water of Elelenwo River, Rivers State, Niger Delta, Nigeria. Their study observed that the levels of conductivity and turbidity were above the limit recommended for domestic water by WHO. The study however noted that other variables including TSS, TDS, temperature, $\mathrm{pH}$, and salinity were within acceptable limits. Etim et al. (2013) reported the water quality index for the assessment of water quality from different sources in the Niger Delta region of Nigeria. Their report revealed that all the borehole and pipe-borne water samples analyzed are fit, potable, and can be used for other domestic purposes. The stream water samples were found unfit and thus not potable, going by the water quality index standard applied in the study.

Assessment of the Physicochemical Parameters of Bodo Creek, Pre-Spill, and Post-Spill: Traditionally, Bodo Creek is a strong livelihood support base for the people of the area and even beyond. The creek is used for fishing and subsistent agriculture, transportation, cassava fermentation, production of fuel wood, and disposal of domestic waste. Also, the quietness around the mangrove-sheltered waterfronts provides the necessary haven to relax and for solitude. Moreover, mangrove canopy and moveable spaces under the shade are a source of benign defecation environment for the locals (Onwugbuta-Enyi et al., 2008). According to Zabbey and Hart (2014) the bulk of periwinkle, Tympanotonus fuscatus that are sold in the markets of Bodo, Bori, and Onne communities come from Bodo Creek. They also reported that some industrial development such as an uncompleted 500 hectares fish farm owned by the Niger Delta Basin Development Authority (NDBDA) and Bodo West Oilfield is supported by the Creek. Their study further revealed that the interaction of environmental factors structures biological communities. Also, biotic and abiotic variables influence one another, mostly in complicated fashions that cannot be easily explained. A major challenge facing the assessment and monitoring of fluvial systems and wetland restoration is the paucity of pre-impact data. How biotic components recover is linked directly to improvement in Physico-chemical variables of the focal catchment (Zabbey and Arimoro, 2017). However, several studies have been carried out in Bodo Creek to assess Physico-chemical parameters pre-spill (OnwugbutaEnyi et al., 2008; Zabbey and Arimoro, 2017; Zabbey, 2012) and post-spill (Vincent-Akpu et al., 2015; Eludoyin et al., 2018; Nwipie et al., 2019). From figure 1 , there was a decrease in mean dissolved oxygen (DO) and an increase in mean biological oxygen demand (BOD) post-spill. After the oil spill, there was a marginal increase in mean $\mathrm{pH}$. There was a decrease in mean salinity and mean temperature after the oil 
spill.To compare the pre-spill and post-spill levels of $\mathrm{pH}$, salinity, DO, BOD, and temperature in Bodo
Creek, the average values of these parameters in tables 1 and 2 were subjected to a t-test in SPSS version 23.

Table 1: Pre-spill Physicochemical parameters of Bodo Creek

\begin{tabular}{|c|c|c|}
\hline Reference and data collection date & Parameter & Range \\
\hline Onwugbuta-Enyi et al. (2008) & Temperature & $26.7-30.1^{\circ} \mathrm{C}$ \\
\hline \multirow[t]{3}{*}{ December 2005-July, 2006} & $\mathrm{pH}$ & $6.5-8.6$ \\
\hline & Salinity & $11.6-16.1$ \\
\hline & DO & $4.6-11.8 \mathrm{mg} / \mathrm{L}$ \\
\hline Zabbey (2012) & Temperature & $25-34^{\circ} \mathrm{C}$ \\
\hline \multirow[t]{3}{*}{ May, 2006-April, 2008} & $\mathrm{pH}$ & $6.64-8.10$ \\
\hline & Salinity & $5-28 \mathrm{psu}$ \\
\hline & DO & $0-7.60 \mathrm{mg} / \mathrm{L}$ \\
\hline \multirow{4}{*}{ Zabbey and Arimoro (2017) } & Temperature & $25.3-34^{\circ} \mathrm{C}$ \\
\hline & & $6.6-8.6$ \\
\hline & $\mathrm{BOD}_{5}$ & $10.89-14.64 \mathrm{mg} / \mathrm{L}$ \\
\hline & Alkalinity & Lowest $(7.46 \mathrm{mg} / \mathrm{L})$ \\
\hline \multicolumn{3}{|c|}{ Table 2: post-spill physicochemical parameters of Bodo Creek } \\
\hline Reference and data collection date & Parameters & Range \\
\hline Vincent-Akpu et al. (2015) & Temperature & $26.7-27.8^{\circ} \mathrm{C}$ \\
\hline \multirow[t]{8}{*}{ September 2011-January, 2012} & $\mathrm{pH}$ & $8.8-8.9$ \\
\hline & DO & $4.7-5.5 \mathrm{mg} / \mathrm{L}$ \\
\hline & BOD & $13-19 \mathrm{mg} / \mathrm{L}$ \\
\hline & COD & $24-44 \mathrm{mg} / \mathrm{L}$ \\
\hline & Salinity & 2580-16200mg/L \\
\hline & TDS & $3070-188000 \mathrm{mg} / \mathrm{L}$ \\
\hline & Conductivity & $195-287 \mathrm{~ms} / \mathrm{cm}$ \\
\hline & Total hardness & $151-453 \mathrm{mg} / \mathrm{L}$ \\
\hline Eludoyin et al. (2018) & Salinity & $8.12-15.31 \mathrm{ppt}$ \\
\hline December 2017 & DO & $1.50-3.31 \mathrm{mg} / \mathrm{L}$ \\
\hline Nwipie et al. (2019) & $\mathrm{pH}$ & $5.9-8.6$ \\
\hline \multirow[t]{5}{*}{ September 2015-February, 2016} & Temperature & $27.0-31.2^{\circ} \mathrm{C}$ \\
\hline & DO & $1.1-4.5 \mathrm{mg} / \mathrm{L}$ \\
\hline & Conductivity & $10.0-27.5 \mathrm{~ms} / \mathrm{cm}$ \\
\hline & TDS & $2.0-18.4 \mathrm{ppt}$ \\
\hline & BOD & $8.0-51.2 \mathrm{mg} / \mathrm{L}$ \\
\hline
\end{tabular}

Table 3: Mean and standard error of the mean (SEM) for pre-spill and post-spill Physico-chemical parameters in Bodo Creek

\begin{tabular}{lllc}
\hline Parameter & Pre-spill $($ Mean \pm SEM $)$ & Post-spill $($ Mean \pm SEM $)$ & P-Value \\
\hline pH & $8.60 \pm 0.00$ & $8.75 \pm 0.15$ & 0.423 \\
Salinity & $22.05 \pm 5.95$ & $15.76 \pm 0.45$ & 0.402 \\
DO & $9.70 \pm 2.10$ & $4.41 \pm 1.10$ & 0.155 \\
BOD & $11.42 \pm 3.22$ & $35.10 \pm 16.10$ & 0.286 \\
Temperature & $32.05 \pm 1.95$ & $29.50 \pm 1.70$ & 0.428 \\
\hline
\end{tabular}

Table 3 shows the result of the statistical analysis. From table 3, the difference in $\mathrm{pH}$ between the prespill study and post-spill study was not statistically significant $(\mathrm{P}>0.05=0.423)$. The difference in salinity between the pre-spill study and post-spill study was not statistically significant $(\mathrm{P}>0.05$ $=0.402)$. There was no statistically significant difference in DO $(\mathrm{P}>0.05=0.155)$ between pre-spill and post-spill studies. There was no statistically significant difference in BOD $(\mathrm{P}>0.05=0.286$ ) between pre-spill and post-spill studies. The difference in temperature between the pre-spill and the post-spill study was not statistically significant $(\mathrm{P}>0.05$ $=0.428)$. Figure 1 shows that BOD was significantly higher after the oil spill. This higher level of BOD is a result of the pollution from the oil spill. From figure 2, a comparison of all the pre-spill and post-spill physicochemical parameters shows no statistically significant difference $(\mathrm{P}>0.05)$.

Pre-Spill Study: Before the two major oil spills in Bodo Creek in 2008, several studies were carried out in the creek to investigate the water quality of the creek. This review examines three of the pre-spill studies on the physico-chemical parameters of the creek.

Case study 1:Onwugbuta-Enyi et al. (2008) investigated the water quality of Bodo Creek in the Lower Niger Delta Basin. The study revealed that significant variations $(\mathrm{P}<0.05)$ in temperature occurred across the sampled months, with a peak in February; higher $\mathrm{pH}$ values were recorded in the wet months compared to the dry months. The study also reported a peak in salinity and BOD in February and 
July respectively. Variations in dissolved oxygen (DO) between months were significant $(\mathrm{p}<0.05)$.

Case study 2:In a study on the environmental forcing of intertidal benthic macrofauna of Bodo Creek by Zabbey and Arimoro (2017), they reported that the monthly mean temperature varied significantly, with the highest mean value in March and least value in August. From the study, hydrogen ion concentration, $\mathrm{pH}$, lowest values were recorded in September and November, while it peaked in June and December. The monthly mean salinity was highest in March, while the least mean values were reported in September and August. Conductivity decreased from May to November, at which time it was least, and started to increase in December with a peak in April. Monthly Mean DO values were almost similar except in September and April that recorded highest and lowest DO, respectively; DO in these months varied statistically from other months. The study also revealed that the mean alkalinity $(\mathrm{mg} / \mathrm{l})$ value fluctuated significantly (ANOVA $=2.85>\mathrm{P}$ (2.13)0.05) between months.

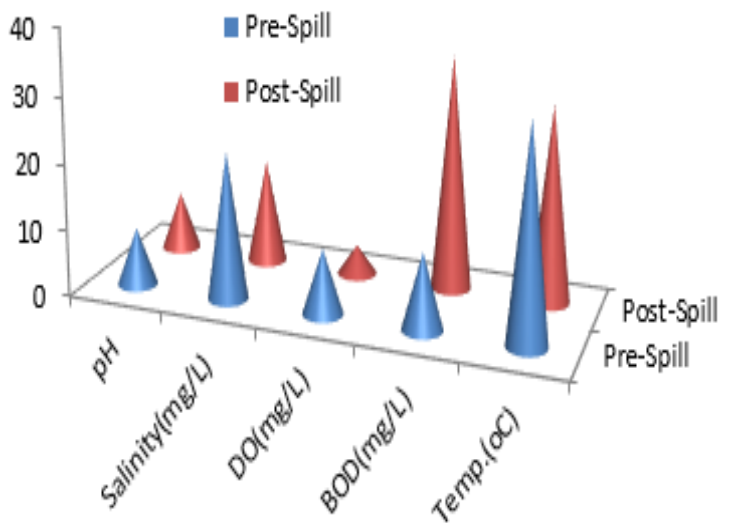

Fig 1: Average pre-spill and post-spill levels of Physico-chemical parameters in Bodo Creek

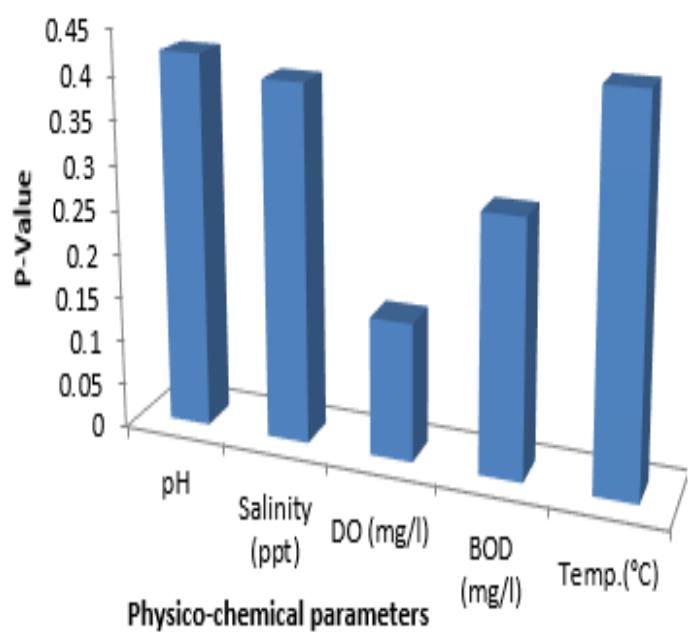

Fig 2: P-Value for pre-spill and post-spill physicochemical parameters
Case study 3: A study of the spatial and temporal variability in interstitial water quality of soft-bottom flats at Bodo Creek was conducted by Zabbey (2012). From the study, mean temperatures varied significantly between months, with a peak and least value in March and August respectively. Mean $\mathrm{pH}$ value was least in November, highest in December, and was similar in the wet and dry seasons. Salinity was highest in March and least in September. The dry season had significantly higher mean salinity. DO was highest in September.

Post-Spill Study: After the 2008 devastation of Bodo Creek by two major oil-spills, scientists over time have carefully assessed the physico-chemical parameters in the creek. Three of such studies are briefly reviewed below.

Case study 1:Vincent-Akpu et al. (2015), assessed the physicochemical properties of water in Bodo Creek. The study showed a temperature range that is typical for the Niger Delta region. Salinity increased with the onset of the dry season. The study also revealed that the mean BOD, COD, and total hardness were above the Department of Petroleum Resources (DPR) (2002) acceptable maximum permissible limits for domestic use in Nigeria.

Case study 2:The spatial assessment of heavy metal concentrations in giant tiger shrimps in Bodo Creek by Eludoyin et al. (2018), showed a weakly acidic $\mathrm{pH}$ of the water surface. The study further revealed a higher concentration of conductivity and salinity in the upstream, with the highest DO in the midstream. The $\mathrm{pH}$ was lower than the permissible levels except that of the upstream that was within the WHO/EPA permissible range. However, the mean DO, conductivity, salinity, and temperature of surface water in Bodo Creek was less than the EPA permissible levels.

Case study 3: Nwipie et al. (2019) investigated the recovery of infaunamacrobenthic invertebrates in oilpolluted tropical soft-bottom tidal flats of Bodo Creek, seven years after the spill and discovered that all the physicochemical factors followed a similar Spatiotemporal trend as recorded during the pre-spill baseline studies.

Pre-Cleanup and Post-Cleanup Physicochemical Parameters of Bodo Creek: After the two major oil spills in Bodo Creek in 2008, SPDC commenced the cleanup of the creek in 2019. After the cleanup, Nkeeh (2021), assessed the Physico-chemical parameters of the creek. The post-cleanup study was conducted at the four stations previously sampled by Nwipie et al. (2019) before the clean-up. 


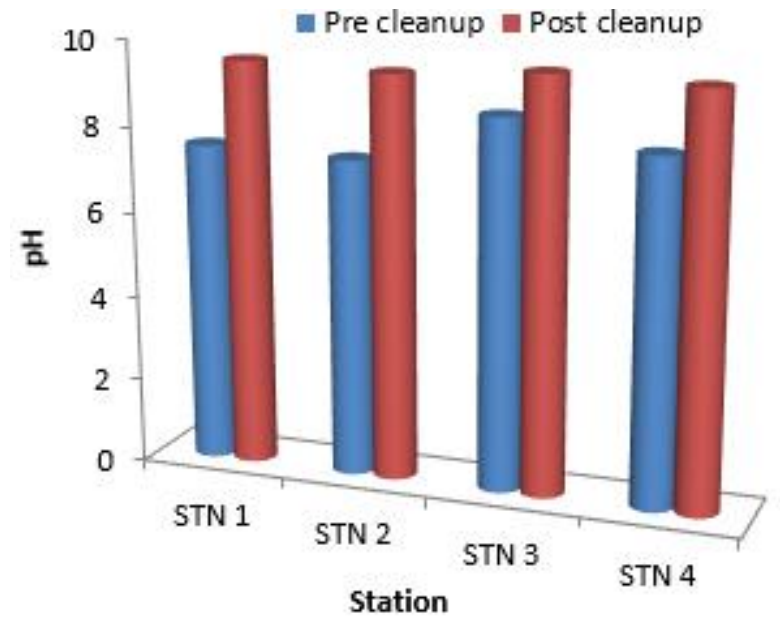

Fig 3: Pre-cleanup and post-cleanup variation in $\mathrm{pH}$

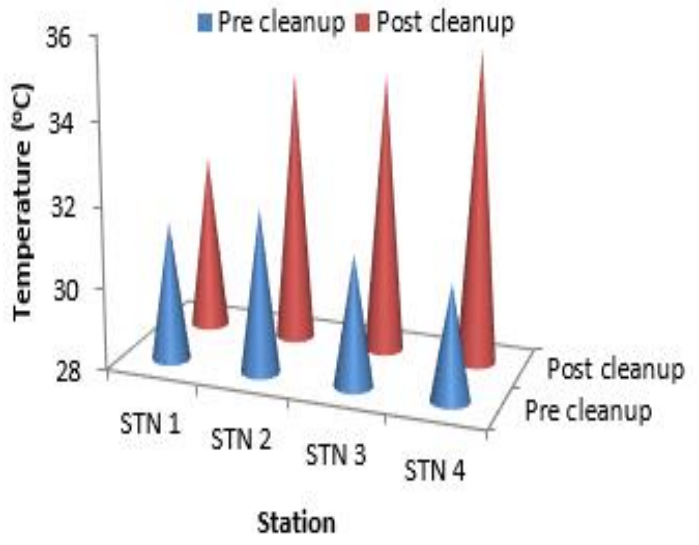

Fig 4: Pre-cleanup and post-spill variation in temperature

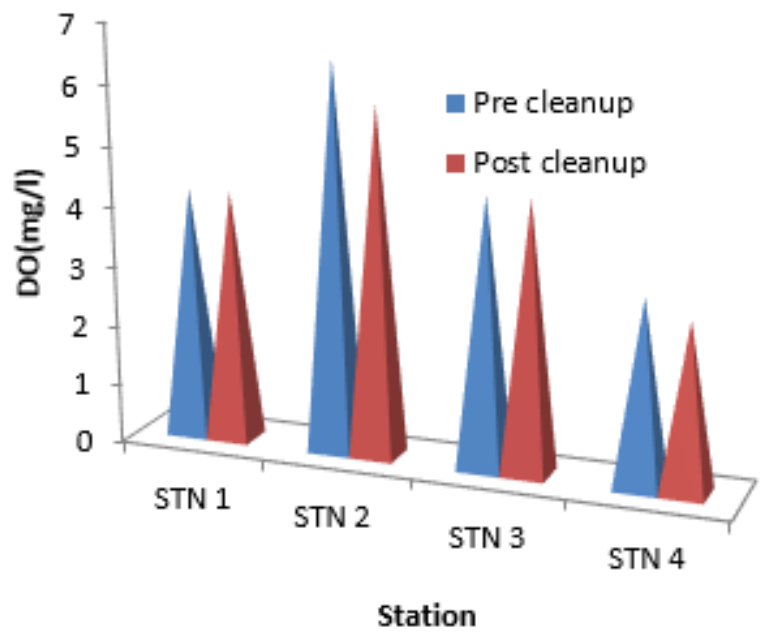

Fig 5: pre-cleanup and post-cleanup variation in DO

It is worthy of note that while Nkeeh (2021) evaluated the Physico-chemical parameters of the four study stations, oil spill cleanup was still going on in other parts of Bodo Creek outside the study stations. This review, therefore, compares the level of $\mathrm{pH}$, temperature, dissolved oxygen (DO), and conductivity from the pre-cleanup and post-cleanup studies in the four sampled stations. From figure 3, the level of $\mathrm{pH}$ after the oil spill clean-up was higher than the $\mathrm{pH}$ level before the clean-up, in each of the four stations. Figure 4 shows that pre-clean-up temperature was lower than post-clean-up temperature, in each of the four stations. From figure 5, post-clean-up DO was relatively lower than pre-clean-up DO throughout the four study stations. Figure 6 shows that conductivity before the clean-up was higher than the conductivity after the clean-up, in each of the four stations.

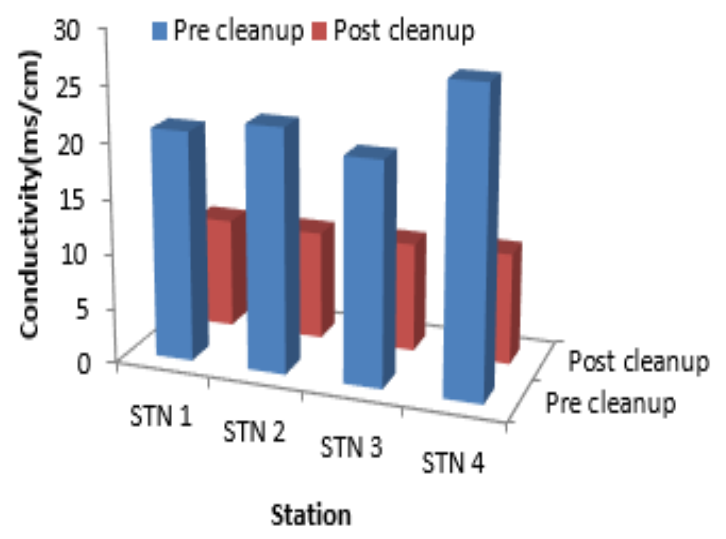

Fig 6: Pre-cleanup and post-cleanup Conductivity

Conclusion:The difference in the levels of the physicchemical parameters in Bodo Creek, before and after the oil spill was not statistically significant. Generally, $\mathrm{pH}$ and temperature were higher in the post-clean-up study, while DO and conductivity were higher in the pre-clean-up study. This review, therefore, helps to better understand the changes in the environment as a result of any human intervention such as the oil spill clean-up.

\section{REFERENCES}

Adeyemo, OK; Adedokun, OA; Yusuf, RK; Adeleye, E A (2008). Seasonal changes in Physico-chemical parameters and Nutrient load of river sediments in Ibadan city, Nigeria. Globl. NEST J.,10(3): 326336.

Arain, MB; Kazi, TG; Jamali, MK;. Afridi, HI; Baig, JA; Jalbani, N; Shah, AQ (2008). Evaluation of Physico-chemical parameters of Manchar Lake water and their comparison with other global published values. Pak. J. Anal. Environ. Chem. Vol. 9, No. 2.

Attah, T (2012). Oil theft and artisanal (illegal) refining in Nigeria-scale, impacts and the need for 
a multi-dimensional response" Chatham House Gulf of Guinea Security Conference, London.

Awah, TM (2008). Water Pollution of the Nkoup River System and its environmental impact in Foumbot, An Agricultural Town in Western Cameroon. Ph.D. Thesis, University of Yaounde I, Cameroon. 209p.

Bhandari, NS; Nayal, K. (2008). Correlation study on Physico-chemical parameters and quality assessment of Kosi River Water, Uttarakhand. E-J of Chem. 5(2): 342-346.

Daniel-Kalio, LA; Braide, SA (2002). The Impact of Accidental Oil Spill on Cultivated and Natural Vegetation in a Wetland Area of Niger Delta, Nigeria. AMBIO: A J. of the Humn.Environ., 31(5):441-442.

Encyclopedia Britanica, Inc., EBI (2021).

Edori, OS; Iyama, WA; Amadi, MQC (2020). Variation of some Physico-chemical parameters in surface water of Elelenwo River, Rivers State, Niger Delta, Nigeria. Intl. J. of Res. and Sci.Innov. (IJRSI) 7(5): 2321-2705.

Eludoyin, OS;Balogun, AN; Otali, SO (2018). Spatial assessment of heavy metal concentrations in giant tiger shrimp (PenaeusmonodonFabricius 1798) in Bodo Creek, Gokana LGA, Rivers State, Nigeria. Ukr. J. of Ecol., 8(3): 340-348.

Etim, EE; ,Odoh, R; Itodo, A U; Umoh, SD; Lawal, U (2013). Water quality index for the assessment of water quality from different sources in the Niger Delta Region of Nigeria. Front. in Sci., 3(3):89-95.

Gebreyohannes, F; Gebrekidan, A; Hadera, A; Estifanos, S (2015). Investigations of Physicochemical parameters and its pollution implications of Elala River, Mekelle, Tigray, Ethiopia. http://dx.doi.org/10.4314/mejs.v7i2.7.

Ko, JY; Day, JW (2004). A review of ecological impacts of oil and gas development on coastal ecosystems in the Mississippi Delta. Ocn. Coast Manag. 47:579-623.

Kotta, J; Martin, G; Aps, R (2007). Sensitivity of benthic vegetation and invertebrate functional guilds to oil spills and its use in oil contingency management-related negotiation processes. Proc Estonian Acad Sci Biol Ecol 56(4):255-269.
Linden, O; Palsson, J (2013). Oil contamination in Ogoniland, Niger Delta. Ambio, 42; 685-701.

Mezgebe, K.; Gebrekidan, A; Hadera, A; Weldegebriel, Y (2015). Assessment of Physicochemical parameters of TsaedaAgam River in Mekelle City, Tigray, Ethiopia. Bull. Chem. Soc. Ethiopia. 29(3):377-385.

Niger Delta Development Commission, NDDC (2001). Niger Delta Regional Masterplan. Federal Government of Nigeria.

Nkeeh, DK; Hart, AI; Erondu, ES; Zabbey, N (2021). Assessment of macrozoobenthos in Bodo Creek: a review. Intl. J. of Sci. and Eng. Res. 12(4): 294299.

Nwipie, GN; Hart, AI; Zabbey, N; Sam, K.; Prpich, G; Kika, P E (2019). Recovery of infaunamacrobenthic invertebrates in oil-polluted tropical softbottom tidal flats: 7 years post-spill. Environ. Sci. Pollut. Res. https://doi.org/10.1007/s11356-019-05352-2

Okonta, I (2008). When Citizens Revolt: Nigerian Elites, Big Oil and the Ogoni Struggle for Self Determination. Ofirima Publishing House, Port Harcourt, Nigeria.

Onwugbuta-Enyi, J; Zabbey, N; Erondu, E S (2008). Water quality of Bodo Creek in the lower Niger Delta basin. Adv. Environ. Biol. 2:132-136.

OPEC (2017). Annual Statistical Bulletin 2017, The American Economy: Essays and Primary Source Documents (DOI: ISSN 0475-0608).

Sam, K.; Coulon, F; Prpich, G (2017a) Management of petroleum hydrocarbon contaminated sites in Nigeria: current challenges and future direction. Land Use Policy 64:133-144. https://doi.org/10.1016/j. landusepol.2017.01.051

Sibe, L; Osuji, LC; Hart, AI (2019). Physico-chemical alterations of interstitial water quality by artisanal refining operations at K-Dere coastal plain, SouthEastern Nigeria. Intl. J. of Sci. and Eng. Res.10(12): 194-205.

Simpi, B; Hiremath, SM; Murthy, KNS; Chandrashekarappa, KN; Patel, A N; Puttiah, ET (2011). Gbl J. of Sc. Front. Res. Volume 11 Issue 3 Version 1.0 May 2011. 
Smeltz, M; Rowland-Faux, L;Ghiran, C; Patterson, WF; Garner, SB; Beers, A;Mièvre, Q; Kane, AS; James, MO (2017) A multi-year study of hepatic biomarkers in coastal fishes from the Gulf of Mexico after the Deepwater Horizon oil spill. Mar Environ Res $129: 1-11$ https://doi.org/10.1016/j.marenvres.2017.04.015

UNEP (2011). Environmental Assessment of Ogoniland. UNEP, Switzerland

Venosa, AD; Zhu, X (2005). Guidelines for the remediation of oil-contaminated wetlands, marshes, and marine shorelines. Pages 141-172 in M. Fingerman and R. Nagabhushanam (eds), Bioremediation of aquatic and terrestrial ecosystems. Erifield, NH: Science Publishers.

Vincent-Akpu, IF; Tyler, A.N; Wilson, C; Mackinnon, G (2015). Assessment of Physico-chemical properties and metal contents of water and sediments of Bodo Creek, Niger Delta, Nigeria. Toxicol. Environ. Chem. 97(2):135-144

Vincent-Akpu, IF; Nwachukwu, LC (2016). Comparative Water Quality Assessment of Nembe, Bonny, and Iwofe Ferry terminals in Port Harcourt, Nigeria. J. Environ. Sci., Toxicol. Food Tech. 10(7): 15-19.
Vincent, DA; Ugbomeh, AP; Nwabueze, E (2020).The Physico-chemical parameters of Kalaigidama and Basambio Creeks, Kein Rivers State, Nigeria.Afr. J. of Environ. Nat. Sci. Res. 3(2):13-21

Zabbey, N. (2012). Spatial and temporal variability in interstitial water quality of soft-bottom flats at Bodo Creek, eastern lower Niger Delta, Nigeria. Tropcl. Fwat. Biol., 21 (1):83 - 103.

Zabbey, N; Arimoro, FO (2017). Environmental forcing of intertidal benthic macrofauna of Bodo Creek, Nigeria: preliminary index to evaluate cleanup of Ogoniland. Reg Stud Mar Sci 16:89-97.

Zabbey, N; Hart, AI (2014). Spatial variability in macrozoobenthic diversity in tidal flats of the Niger Delta, Nigeria: the role of substratum. Afr. J. Aquat. Sci. 39: 67-76.

Zabbey, N; Uyi; H (2014). Community Responses of intertidal soft bottom macrozoobenthos to oil pollution in a tropical mangrove ecosystem, Niger Delta, Nigeria. Mar. Pollut. Bull. 82: 167-174. 